\title{
Diversity in the News? A Study of Interest Groups in the Media in the UK, Spain and Denmark
}

\author{
ANNE SKORKJÆR BINDERKRANTZ, LAURA CHAQUÉS BONAFONT AND \\ DARREN R. HALPIN*
}

This article provides the first systematic cross-country analysis of interest group appearances in the news media. The analysis included three countries - the UK, Spain and Denmark - each representing one of Hallin and Mancini's ${ }^{1}$ three overall models of media and politics: the liberal system, the polarized pluralist system and the democratic corporatist system. It finds important similarities across countries with high levels of concentration in media coverage of groups, more extensive coverage of economic groups than citizen groups, and differential patterns of group appearances across policy areas and between right- and left-leaning papers. It also identifies country variation, with the highest degree of concentration among group appearances in Spanish newspapers and the most attention to economic groups in Danish newspapers.

Every day around the world, reporters choose not only what stories to write but also what sources to include. Gauging the diversity and range of sources that appear in the news is central to a fuller understanding of the democratic role of the media. Of particular importance is the balance of sources representing different societal interests. Are the interests of businesses more commonly heard than those of employees? To what extent are citizen groups representing, for example, social or environmental causes used as sources in news stories? Does the balance between using different interest groups as sources depend on the policy area being reported on? And to what extent does media coverage of interest groups vary across news outlets?

Our current knowledge regarding how and why interest groups get media coverage is scant. ${ }^{2}$ Most analyses are single-country studies, and the few existing comparative studies deal with interest groups as an aggregate category compared to, for example, political parties and bureaucrats. ${ }^{3}$ This article provides the first cross-country study of interest group appearances in the news media. Drawing on the existing literature, we argue that interest group access to the media largely depends on media preferences. ${ }^{4}$ Media attention is limited, and reporters rely on journalistic norms when choosing which sources to include in news stories. In effect, attention is heavily concentrated among a small number of groups, and economic groups receive a higher proportion of attention than citizen groups.

The range of voices expressed in the news is an indicator of the democratic quality of media systems. Democracy functions best when its citizens and decision makers are informed about different viewpoints on policy problems. ${ }^{5}$ Hence, a main concern of media and agenda-setting

* Department of Political Science, Aarhus University (email: asb@ps.au.dk); Institut Barcelona d'Estudis Internacionals (email: lchaques@ibei.org); Research School of Social Sciences, Australian National University (email: darren.halpin@anu.edu.au). This research was supported by the Danish Council for Independent Research, grant no. 0602-01212B. Data replication sets are available at http://dataverse.harvard.edu/dataverse/ BJPolS and online appendices are available at http://dx.doi.org/doi:10.1017/S0007123415000599.

1 Hallin and Mancini 2004.

2 See however, Binderkrantz (2012); Binderkrantz and Christiansen (2013); Danielian and Page (1994); Halpin, Baxter, and MacLeod (2012); Thrall (2006).

3 Dimitrova and Strömbäck 2009; Tiffen et al. 2014.

4 Binderkrantz 2012; Danielian and Page 1994; de Bruycker and Beyers 2015; Thrall 2006.

5 Tiffen et al. 2014. 
scholars is assessing whether the media accomplishes its tasks in a way that ensures the inclusion of a wide range of viewpoints and actors in news stories. ${ }^{6}$ The interest group literature shares most of these concerns. In general, a prominent media profile may be seen as a key indicator of interest group success, especially when (1) access is linked with topics interest groups want to politicize and (2) the reporting adopts a positive tone. ${ }^{7}$ Although interest groups also exert influence in other arenas such as parliament and the bureaucracy, ${ }^{8}$ diversity in media appearances indicates diversity in the range of voices that becomes part of the public conversation.

In this study, we take a first step towards furthering our insight into patterns of group appearance in the media by conducting empirical work across three different media and political systems. Our focus is twofold. First, we are concerned with overall patterns of media appearance by groups, and types of groups. Secondly, we concern ourselves with variation in the set of groups that appears in the news across different news outlets and different policy areas. Here, we are able to move closer to some of the factors affecting diversity among group appearances. We are then able to test propositions about parallelism in national media systems, and about the effects of group policy specialization on the distribution of attention within different policy areas.

To explore these questions, the study compares three European countries. Each represents a different model of media and politics: the UK represents the liberal model, Spain the polarized pluralist model and Denmark the democratic-corporatist model. ${ }^{9}$ Across these cases we expect similar patterns of systematic bias in the attention provided to interest groups - detrimentally affecting the diversity in group appearances. The empirical analysis in this article focuses on newspapers. Although electronic media - including new social media - are increasingly important in political communication, newspapers are still central in news production, and many stories appearing in other media have their origin in newspaper reportage. In each country we selected two of the most important newspapers, ensuring we have one right-leaning and one left-leaning title. We recorded all interest group appearances in the newspapers across twenty-six weeks distributed over a full year and included front pages in the remaining weeks.

The article proceeds in four parts. The first substantive section reviews the group literature and develops expectations that we subsequently test. The data utilized in the article are outlined in the subsequent section, followed by a section detailing our empirical results. The final section outlines our conclusions and assesses implications for future work.

\section{GETTING IN THE NEWS: SOME THEORETICAL EXPECTATIONS}

As even the most cursory reader of the print media in democratic nations will be aware, interest groups are often in the news. There are a multitude of good reasons for this to be the case. From a policy perspective, getting into the news might help groups reframe an issue, escalate its salience or mobilize the public as to its importance. The media is a key political venue through which interest groups compete with one another, try to alter the status quo, foster new ideas and policy proposals, and promote policy change. ${ }^{10}$ Several studies have thus demonstrated that groups view media strategies as a central tool for affecting politics. ${ }^{11}$

From a membership viewpoint, media appearances may serve the purpose of reassuring potential and actual group members and supporters that the group is actively pursuing its

6 Aalberg, Aelst, and Curran 2010, 256.

7 Grossman 2012.

8 Binderkrantz, Pedersen, and Christiansen 2015.

9 Hallin and Mancini 2004.

10 Castells 2009; Strömback and van Aelst 2013.

11 Beyers 2004; Binderkrantz 2005; Kriesi, Tresch, and Jochum 2007. 
agenda. Group leaders are constantly aware of the need to maintain and build support for the group; therefore appearing in the media is not only targeted at political decision makers, but also at potential and current group members. ${ }^{12}$ This concern may be particularly pressing for public interest groups that find their supporters among the public at large rather than in specific groups related to, for example, the labor market. ${ }^{13}$

While for interest groups media appearance may generally be seen as a valued asset, there are obvious exceptions. In some instances, groups prefer to stay out of the headlines. For instance, a group may wish to avoid public attention regarding closed-door negotiations with authorities or scandals within groups. However, in most cases there is reason to expect groups to prefer more media attention to less. Groups' capacity to attract media attention is likely to vary significantly. A range of mechanisms is likely to affect their ability to gain media attention, and thus influence the level of diversity in the groups appearing in the media. In this section we review the expectations around variations in group media appearances, and outline the mechanisms at work.

\section{Concentration in Media Appearances}

The relationship between sources and reporters may be seen as one of mutual dependence, in which organized interests and other actors compete in a zero-sum game for control of the public agenda. ${ }^{14}$ In this 'game', groups' capacity to supply content is likely to differ significantly. Thus groups with low levels of financial resources - or those without a dedicated or professional press staff - are likely to be able to 'push' less material (and less convincing material) to journalists. ${ }^{15}$ Thus from a purely group resource perspective, we would expect media appearances to be highly concentrated. Further, the media exercise a good deal of discretion in terms of both what stories to report and the sources used. ${ }^{16}$ Media selection is based on factors for example, status, power and relevance - that make some events and actors newsworthy and therefore increase their chances of making it into the news. ${ }^{17}$

The media tends to concentrate its attention on actors perceived to be legitimate and reliable sources of information due to their position in the political system. ${ }^{18}$ This 'elite status' might be explained by formal rules governing the political system - especially in the case of closed policy communities, or neo-corporatist arrangements - as well as informal rules related to the seniority of an interest group or tradition. ${ }^{19}$ The tendency of reporters to develop common understandings of who the important sources are reinforces this effect: thus groups that attract some media attention will be likely to attract more attention in the future. ${ }^{20}$ If this argument is correct, then we should expect the same groups that dominate the inside game of politics to also be dominant in the media arena. ${ }^{21}$ Thus we expect media appearances to be heavily concentrated among a small number of high-status, well-resourced and legitimate groups.

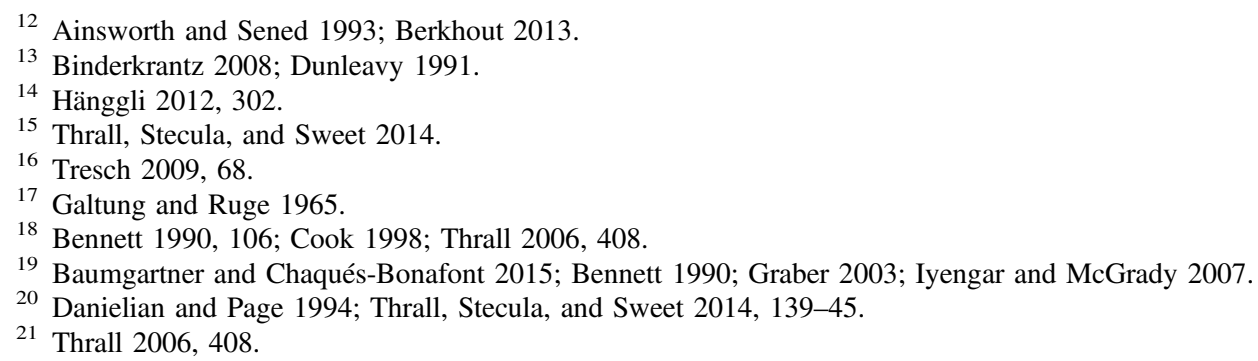




\section{'Bias' across Group Types}

In light of the rising importance of the media as an arena for interest groups, it is of crucial interest to investigate not only the concentration of attention, but also the range of interest group voices heard in the media. Consistent with the interest group literature, ${ }^{22}$ we address diversity by exploring the mix of types of interest groups appearing in news stories. Interest groups are defined as associations of members or other types of supporters working to obtain political influence. Group members can be individuals, firms, governmental institutions or other interest groups. We distinguish between the following categories of groups: (1) trade unions, (2) business groups, (3) institutional groups, (4) professional groups, (5) identity groups, (6) leisure groups and (7) public interest groups.

The first four types are economic groups related to production in the private or public sector. The two first groups are almost indispensable: a classic discussion thus concerns the balance between business and labor, which is of particular interest in the European context because of the tradition of involving labor market groups in corporatist arrangements. ${ }^{23} \mathrm{~A}$ third group type is producers and providers of public services. Local authorities in most countries have established interest groups, and schools, universities, museums and other institutions are organized into associations. These are categorized as 'institutional groups'. Finally, professional groups represent the many different professions represented in the labor market. They are distinguished from trade unions because they do not negotiate work-related terms and conditions.

The last three types of groups may all be seen as citizen groups, but we distinguish between those that represent specific groups of citizens (such as leisure groups and identity groups) and those working for broader causes (for example, public interest groups such as Friends of the Earth or Amnesty International). The latter are distinguished from other groups because they seek ends that will not materially benefit their members. ${ }^{24}$ Identity groups encompass, for example, groups representing demographic or minority groups. Leisure groups' members are united by participating in a common leisure activity.

What might be our expectations here? Economic groups are expected to have more media coverage than other types of groups. These types of organizations have a higher capability to overcome the difficulties of collective action and attracting resources. ${ }^{25}$ In general, economic groups may therefore be expected to have higher levels of resources (be it financial or staff) than citizen groups. Further, they possess resources such as technical information, which gives them a greater chance of attaining an insider position in the political system. ${ }^{26}$ In turn, they may benefit from the media's tendency to give more coverage to actors with insider positions. According to the above, we expect economic groups to obtain a higher share of media attention than other groups.

There are two counterarguments to this expectation. First, some citizen groups may also have news value because they represent broadly appealing causes such as protecting the environment ${ }^{27}$ or ending violence against women. Secondly, citizen groups may be more prone to using outsider tactics such as scaling a construction crane to unfurl banners, engaging in a sit-in or using violence, which are often assumed to be more attractive to the media. ${ }^{28}$

22 Baumgartner et al. 2009; Schattschneider 1975 [1969]; Schlozman, Verba, and Brady 2012.

23 Christiansen 2012; Molina and Rhodes 2002.

24 Berry 1977, 7.

25 Olson 1965

26 Bouwen 2004; Rokkan 1966.

27 Binderkrantz, Pedersen, and Christiansen 2015.

28 See Graber 2003; Iyengar and McGrady 2007; Tilly and Tarrow 2006. 
However, even though citizen groups may also possess news value and engage in strategies that attract attention, their capacity to get into the news has a more variable character. We therefore expect the resources of economic groups to be more important for overall patterns of media coverage.

\section{Differing Patterns across Policy Areas}

Perhaps the most fundamental aspect of a news story is its topic. Most interest groups tend to concentrate their lobbying work on a very small number of policy areas, ${ }^{29}$ and their appearance in the news is therefore highly contingent on the set of stories reported on. ${ }^{30}$ In stories about labor market politics, major trade unions and business groups are among the most relevant sources to include, while reporters drafting stories related to health issues may choose to hear from groups representing doctors, patients or representatives of public authorities responsible for the health system. Thus it is reasonable to expect variation in group appearances across issue areas, and for groups with a broad policy remit to appear more often in the news than policy specialists. In effect, the level of diversity in group appearances will also depend on the policy area in question. Some areas may only attract the attention of a limited number of groups representing the same type of causes, while other areas may attract a much more diverse set of groups.

Previous studies have found highly divergent patterns of group appearances depending on the issue area. Dimitrova and Strömbäck ${ }^{31}$ found different patterns of sources used depending on the issue analyzed, while Tiffen et al. ${ }^{32}$ explain the high number of judicial sources used in Colombia and the UK by reference to the high levels of crime in these countries. In their study of group appearance on television news, Danielian and Page ${ }^{33}$ similarly found evidence of compartmentalization around issue areas. In a longitudinal study of interest groups appearing in the Danish news media, Binderkrantz found some policy areas such as agriculture, business and consumer issues to be highly dominated by business interests, while more diversity was present in news stories related to health or social affairs issues. ${ }^{34}$ We would therefore expect the policy areas most closely related to the functioning of the economy or specific economic sectors to be more dominated by economic interests than areas of more general regulation.

\section{Media Coverage across Newspapers}

Access to the media not only depends on interest group resources and general newsworthiness, but also on journalistic norms and the ideological preferences of the news outlet in question. This relates to the more general concept of political parallelism in the news media. ${ }^{35}$ In many European countries, individual papers historically have had ties to specific parties, and the concept of parallelism implies that a newspaper parallels a party if it is closely linked to that party by organization, loyalty to party goals and the partisanship of its readers. ${ }^{36}$ More recent work has argued that party parallelism has transformed into a more general political parallelism following the transformation of mass political parties. ${ }^{37}$ While the original concept did not refer

29 Halpin and Binderkrantz 2011; Halpin and Thomas 2012.

30 Baumgartner, De Boef, and Boydstun 2008; Boydstun 2013.

31 Dimitrova and Strömbäck 2009, 84.

32 Tiffen et al. 2014, 381-2.

33 Danielian and Page 1994.

34 Binderkrantz 2012, 132.

35 Blumler, McLeod, and Rosengren 1992; Hallin and Mancini 2004; Seymour-Ure 1974.

36 Seymour-Ure 1974.

37 Mancini 2012. 
to the content of newspapers, today a prominent dimension of political parallelism relates to the alignment of newspapers with different ideological, political and cultural views. ${ }^{38}$

In this study, we compare three different models of media and politics. ${ }^{39}$ The UK is characterized as a liberal media model, with high levels of commercialization, high journalist professionalism, and moderate partisanship or political parallelism. While there are clearly papers that could be considered left or right leaning, none have direct one-on-one alignment with political parties. Indeed, papers swing back and forth in their support for a given party during UK general elections. Spain is an example of the polarized pluralist model characterized by newspapers' strong ideological leaning, low journalist professionalism and strong state intervention. ${ }^{40}$ Finally, Denmark exemplifies the democratic corporatist model in which political parallelism has traditionally coexisted with journalistic professionalism, and press freedom has coexisted with a tradition of strong state intervention in the media. While historically there were close links between parties and the press, these have eroded. Yet the editorial content of papers may still privilege one party or another. ${ }^{41}$

While differences may exist across these countries, our overall expectation is that we can find evidence of political parallelism in the inclusion of interest groups in news stories in all three countries. Ties between papers and parties have generally loosened, but in today's overcrowded media markets, many news outlets compete not for a mass audience, but for their own niche audience as identified by cultural, ideological and political commonalities. ${ }^{42}$ This may affect not only the choice and framing of stories, but also the type of sources used by different news outlets. Existing analysis supports this argument. For example, despite their strong ideological differences, the two leading newspapers in Spain cover the same topic areas with little variation over time, but important differences exist across these papers when they make explicit references to political parties. ${ }^{43}$ In the same vein, studies of interest group appearances in Danish newspapers demonstrate that the more left-leaning newspapers allow more room for trade unions and public interest groups, while right-leaning papers provide business groups with more attention. ${ }^{44}$ Based on these findings, our final expectation is therefore: interest group media appearances will differ across newspapers depending on their ideological leaning.

In conclusion, we expect a pattern of concentration in the use of interest groups as media sources. A relatively small number of groups is expected to get the lion's share of attention, and economic groups are expected to be at an advantage vis-à-vis citizen groups. Group appearances are also expected to vary across policy areas, and we expect differing patterns of source use depending on the political orientation of the news outlet.

\section{DATA AND RESEARCH DESIGN}

The countries included in this study exemplify three different models of media and politics: the UK the liberal model, Denmark the democratic corporatist system and Spain the polarized pluralist country. ${ }^{45}$ These systems are marked by differences in state laws and regulations, links between media and political parties, and journalistic professional traditions. Historically, they

38 Allern and Blach-Ørsten 2011, 95; Mancini 2012, 266.

39 Hallin and Mancini 2004.

40 Chaqués-Bonafont and Baumgartner 2013; Gunther and Mughan 2000.

41 Allern and Blach-Ørsten 2011, 92-8.

42 Mancini 2012, 267.

43 Baumgartner and Chaqués-Bonafont 2015.

44 Binderkrantz and Christiansen 2010, 2013.

45 Hallin and Mancini 2004. 
also exhibit very different patterns of interest group representation. While all our countries are European, within this limitation, the research design is a most-different-systems design. For each country, we include two of the most widely read national newspapers (one left leaning and one right leaning).

In the UK, the study compares media coverage on interest organizations in The Daily Telegraph, which has a relative conservative readership, with that of the left-leaning The Guardian. ${ }^{46}$ For research design purposes the UK is our 'liberal' case, however we leave open the possibility that it is not perhaps the paradigm example in relation to the degree of parallelism. In Spain we compare the two most widely read newspapers: El Pais (left leaning) and El Mundo (right leaning). Finally, in Denmark we assess the left-leaning Politiken and the Jyllands-posten, which is self-described as an independent liberal paper. ${ }^{47}$

In each case, to identify interest groups appearing in the papers, all articles in the first section and the business section were read, and articles mentioning interest group sources were recorded. Articles that were clearly non-political were left out of the analysis. We also omitted articles in which a group was framed negatively (for example, misconduct by group leaders), as these do not constitute meaningful group access to the media.

All groups identified were coded by the research group and student coders into the group types specified above (with a reliability test resulting in a Cohen's kappa of 0.91 for Denmark; 0.76 for the UK and 0.82 for Spain). The coding periods were chosen to include a full year in which no parliamentary election took place. For Spain and the UK the period covers 2010-11, while the period for Denmark is 2009-10. For this period we coded all front pages and half of all editions from the two newspapers. Specifically, we coded two full weeks, skipped two weeks, coded two weeks and so forth. This strategy was chosen to maximize the spread of news stories across different policy areas. In total we identified 3,266 group appearances in the UK, 1,754 in Spain and 3,672 in Denmark.

While the research strategy is designed to spread our sample of articles - and thus of group appearances - over a full year and across as many different issues as possible, it is evident that some issue areas may be more prominent on the news agenda during this period than others. Most notably this is the case for stories related to the financial crisis. Overall, this may increase the number of appearances by groups representing, for example, the financial sector and relevant trade unions, but also - as will be seen in the case of Spain - groups that were formed in opposition to official policies in response to the crisis. The interpretation of results must be made in light of this potential bias; yet owing to the media's focus on a smallish number of policy issues at a time, any time period has the same potential for bias.

\section{ANALYZING INTEREST GROUPS IN THE MEDIA}

\section{How Attention Is Distributed between Different Group Types}

This section analyses group appearances in newspapers across the three countries. We first address the issue of concentration in media attention, both in the distribution of attention to individual groups and across group types. Secondly, we examine the differences across newspapers and policy areas.

The first issue concerns the distribution of media appearances in our sample of newspapers. Even in a political system resembling a so-called pluralist heaven, we would hardly expect all

46 Hallin and Mancini 2004, 213.

47 Hjarvard 2008, 80-1. 
groups appearing in the news media to get equal amounts of attention. After all, some groups represent very broad and encompassing interests and may therefore continually be relevant for news stories. Other groups are much more narrowly oriented, and their interests coincide with the news agenda only rarely. ${ }^{48}$ So what did we find?

Figure 1 displays the relationship between the number of groups and accumulated share of appearances for each country. It indicates a heavy concentration of mentions among a small number of interest groups. In all three countries, the graphs rise quickly, indicating that a small number of groups accounts for a large percentage of the attention.

Although the curves for each country share the same shape, meaningful differences are found across the three countries. In Spain, the pattern of inequality is particularly marked. Just seven groups (corresponding to 2 per cent of all groups) get half of all attention, and the total number of groups identified in the articles is lower than in the two other countries. The UK has the most diverse pattern of attention: forty-three groups (6 per cent of all groups) account for 50 per cent of all attention, and 693 groups were found in the articles. The pattern in Denmark is in between: twenty-five groups ( 5 per cent of all groups) get half of the attention, and about 500 unique groups were identified. This pattern is also evident in different levels of Shannon's H (normalized) across the three countries: for UK 0.84, Spain 0.72 and Denmark 0.80 . This measure captures the diversity in attention across all groups appearing in the media; the numbers indicate that the diversity in media appearances is highest in the UK and lowest in Spain. ${ }^{49}$

Notwithstanding this variation in degree across our three national cases, the general pattern is for a small number of groups to account for a disproportionate number of appearances. With so few groups getting such a large share of all media attention, it is interesting to take a closer look at these groups. Most of the groups at the top of the list in each of the three countries are large and encompassing economic groups. In the UK, the three most commonly appearing groups are the Confederation of British Industry, Unite the Union and Trade Union Congress. In Denmark, the Confederation of Danish Industry received the most coverage, and it is also noteworthy that Local Government Denmark, which organizes the local authorities in the highly decentralized Danish government structure, is very prominent in the news media. Finally, the Spanish trade unions receive much media coverage, with the General Union of Workers occupying the first spot on the list. The Spanish list also testifies to the importance of the financial crisis, with the anti-austerity 15-M Movement attracting much media attention.

But are economic groups in general getting more attention than other types of groups? Our next core question was to assess the patterns of group appearances in the national print media to determine whether a dominance of economic groups could be found. A difficulty of assessing bias in interest group representation is that there is no way to know what an unbiased pattern would look like. ${ }^{50}$ Our aim is not, therefore, to evaluate the degree to which the media presents a biased picture of the universe of organized interest, but rather to investigate the media logics that affect the diversity in the range of voices heard in news stories. While we will analyze patterns of appearances within specific policy areas below, Figure 2 presents the predicted number of appearances for each type of group across all policy areas. The figure is based on a multivariate regression analysis that includes dummy variables for each group type as well as for countries, and for the interaction between group types and countries. In this model, significant differences (at the 0.001 level) were present when comparing business groups to all other group types, except institutional groups. Regression results may be found in the online appendix.

48 Halpin and Binderkrantz 2011.

49 Boydstun, Bevan, and Thomas 2014; Halpin and Thomas 2012.

50 Lowery and Gray 2004; Schlozman 1984; Schlozman, Verba, and Brady 2012. 


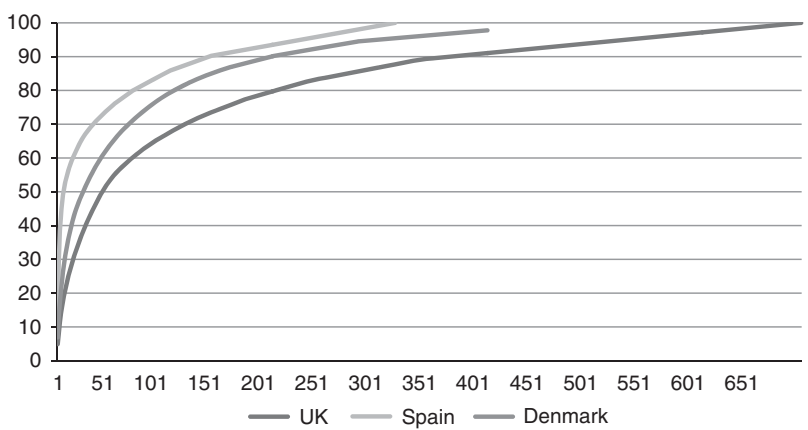

Fig. 1. Distribution of all group appearances (percentage of appearances)

Note: the figure illustrates the number of interest groups accounting for different accumulated percentages of appearances.

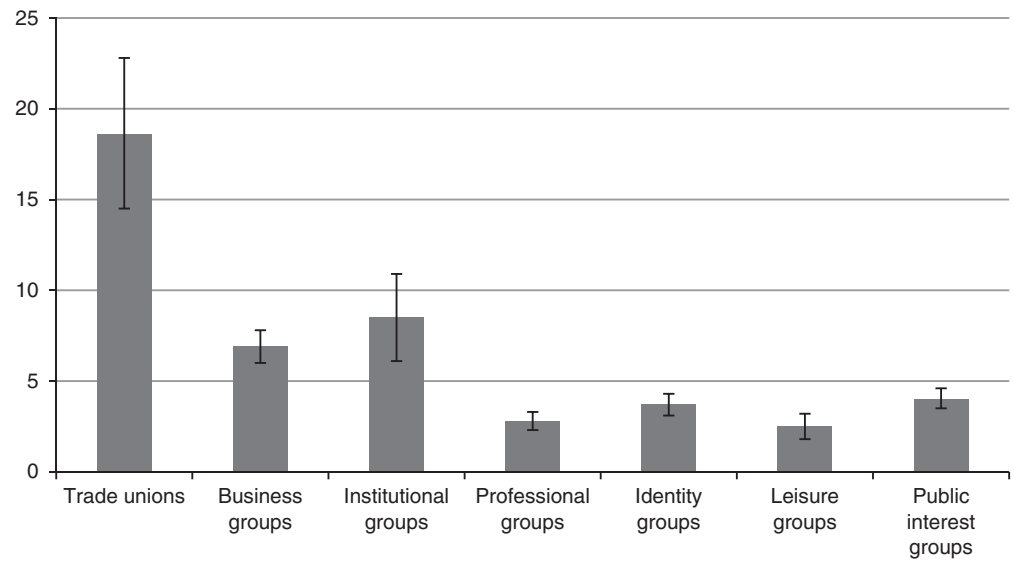

Fig. 2. Predicted number of group appearances

Note: the figure illustrates the average predicted number of appearances based on a negative binominal regression analysis including group types, countries and interaction between these variables as dummy variables (with 95 per cent confidence intervals).

The figure illustrates that, on average, three types of economic groups - trade unions, business groups and institutional groups - receive more media coverage than other types of groups. In particular, trade unions - with an average appearance of almost nineteen articles - are more heavily used as sources than other types of groups. The analysis also shows that professional groups are on a par with citizen groups in their average amount of media coverage. When it comes to country differences (not shown), the regression finds that Danish groups appear more often than groups in the UK (difference significant at the 0.05 level). Overall, this supports the expected dominance of economic groups: each individual economic group appearing in the media is likely to receive more attention than citizen groups. How this affects the level of diversity overall and within specific policy areas is the subject of the next section.

\section{Diversity in Group Appearances: Policy Areas and Newspaper Types}

Patterns of group appearances have so far been analyzed across the range of policy areas covered in news stories. This may mask divergence between different issue areas, as the 


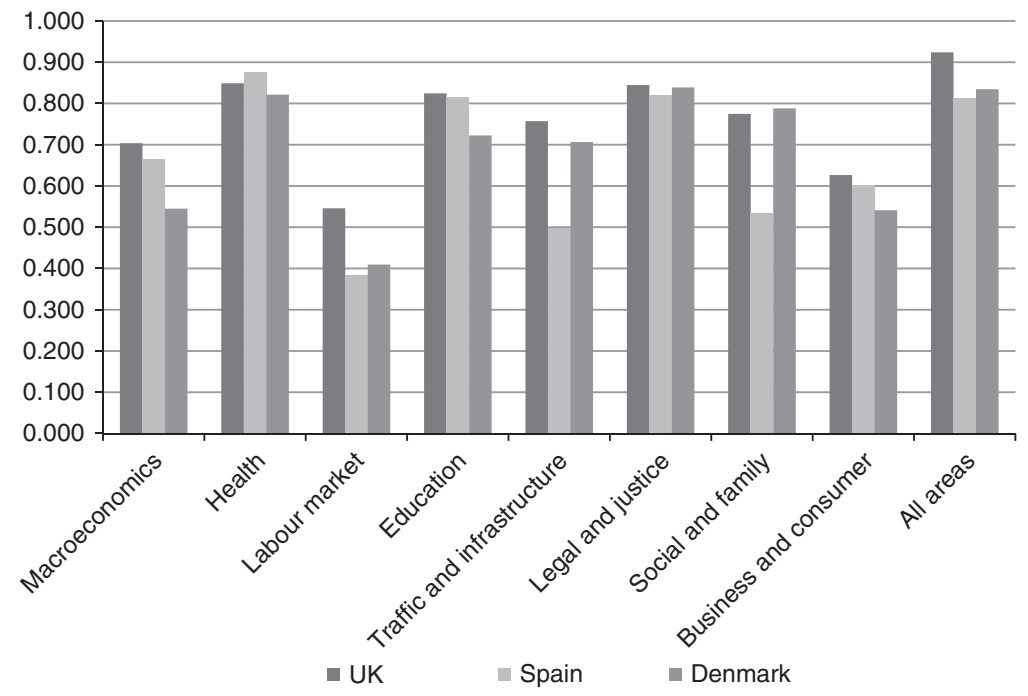

Fig. 3. Diversity in appearances within policy areas (Shannon's $H$, normalized)

Note: the Shannon's H (normalized) is calculated for each policy area based on the distribution of attention across different group types.

relevant sources for news stories obviously depend on the topic of the story. Figure 3 displays diversity in appearances in eight different policy areas (in which at least fifty groups appeared in each country) and compares this with diversity within the data as a whole. While above we calculated diversity based on the appearances of individual groups, here we focus on the distribution of attention across the seven different types of groups.

It is evident that diversity varies across policy areas, and that the overall pattern is similar across the three countries. Diversity is at its lowest in news stories related to the labor market, and at its highest in coverage of health issues, legal and justice issues, and issues related to education. It is also interesting to note that the spread of attention across group types is lower than the spread of attention in the full set of news stories for most policy areas.

To further analyze which groups are getting attention in different policy areas, Table 1 displays the types of groups appearing in four different areas: macroeconomics, labor market issues, legal and justice issues, and social and family issues. These areas have at least one hundred interest group sources appearing in each country.

The overall patterns of group appearances in the three countries correspond to the analysis above, which finds that economic groups are more prominent than citizen groups. While this trend is most pronounced in the Danish case (possibly due to the country's corporatist traditions), trade unions are also particularly successful at gaining attention in Spain. As expected, the patterns of group appearances differ across the four policy areas. ${ }^{51}$ Economic groups are most dominant in issues related to the labor market - and in all countries this is largely explained by the extensive coverage of trade unions. Citizen groups are more prominent in articles covering legal and justice issues in the UK and Denmark because of the high levels of attention given to public interest groups, while identity groups are more prominent in Spain.

\footnotetext{
51 Overall, the share of economic groups ranges from 16 per cent in stories related to refugees and immigration (not a policy area in Table 4) to 97 per cent in stories about the labor market.
} 
TABLE $1 \quad$ Policy Areas and Group Appearances (Column Percentages)

\begin{tabular}{|c|c|c|c|c|c|c|c|c|c|c|c|c|c|c|c|}
\hline & \multicolumn{3}{|c|}{$\begin{array}{l}\text { Macro } \\
\text { economics }\end{array}$} & \multicolumn{3}{|c|}{$\begin{array}{l}\text { Labor } \\
\text { market }\end{array}$} & \multicolumn{3}{|c|}{$\begin{array}{l}\text { Legal and } \\
\text { justice }\end{array}$} & \multicolumn{3}{|c|}{$\begin{array}{l}\text { Social and } \\
\text { family }\end{array}$} & \multicolumn{3}{|c|}{$\begin{array}{l}\text { All policy } \\
\text { areas }\end{array}$} \\
\hline & UK & Spain & DK & UK & Spain & $\mathrm{DK}$ & UK & Spain & DK & UK & Spain & DK & UK & Spain & DK \\
\hline rade unions & 21 & 27 & 31 & 72 & 67 & 72 & 24 & 22 & 37 & 8 & 69 & 37 & 23 & 38 & 29 \\
\hline Business group & 51 & 30 & 57 & 10 & 30 & 22 & 3 & 4 & 16 & 7 & 15 & 3 & 22 & 21 & 32 \\
\hline $\begin{array}{l}\text { Institutional } \\
\text { groups }\end{array}$ & 1 & 0 & 6 & 4 & 0 & 4 & 21 & 1 & 2 & 3 & 6 & 25 & 7 & 1 & 12 \\
\hline $\begin{array}{l}\text { Professional } \\
\text { groups }\end{array}$ & 13 & 4 & 0 & 5 & 3 & 0 & 6 & 16 & 7 & 5 & 2 & 1 & 10 & 7 & 2 \\
\hline $\begin{array}{l}\text { Economic } \\
\text { groups sub } \\
\text { total }\end{array}$ & 87 & 60 & 94 & 90 & 100 & 98 & 54 & 43 & 62 & 23 & 92 & 66 & 63 & 68 & 75 \\
\hline Identity groups & 3 & 3 & 2 & 4 & 0 & 1 & 7 & 34 & 4 & 30 & 4 & 15 & 9 & 16 & 9 \\
\hline Leisure groups & 1 & 0 & 0 & 1 & 0 & 0 & 5 & 2 & 10 & 5 & 0 & 3 & 5 & 2 & 2 \\
\hline $\begin{array}{l}\text { Public interest } \\
\text { groups }\end{array}$ & 9 & 38 & 3 & 4 & 0 & 1 & 35 & 20 & 23 & 43 & 5 & 17 & 24 & 15 & 14 \\
\hline $\begin{array}{l}\text { Citizen groups } \\
\text { sub total }\end{array}$ & 13 & 40 & 6 & 10 & 0 & 2 & 46 & 57 & 38 & 77 & 8 & 34 & 37 & 32 & 25 \\
\hline $\mathrm{N}$ & 413 & 274 & 323 & 303 & 355 & 624 & 239 & 138 & 146 & 186 & 107 & 220 & 3,266 & 1,754 & 3,672 \\
\hline
\end{tabular}

Note: a chi-square test indicates that differences between policy areas are significant $(0.001$ level $)$.

In the two other policy areas, country-specific patterns are more pronounced. It is particularly noticeable that public interest groups are widely mentioned in Spanish articles about macro-economic issues and in UK stories about social and family issues. In the Spanish case this is largely due to a high level of citizen mobilization in reaction to the financial crises (for example, the 15-M Movement), while the UK pattern is probably related to the engagement of a large number of citizen groups in providing social support for vulnerable citizens. ${ }^{52}$ Alongside the overall dynamics related to policy characteristics, more situational factors also affect patterns of group appearance across policy areas. The overall pattern, however, supports our expectation that the policy areas most closely related to the functioning of the economy are more dominated by economic interests than are areas of more general regulation.

Our last question to explore is the issue of political parallelism. We expected right-leaning newspapers to disproportionately favor business groups, and left-leaning papers to give priority to groups traditionally related to the left wing such as trade unions and public interest groups. Table 2 disaggregates the data on media appearances for the two different newspapers examined in each country. For each group type it reports the mean number of mentions in the left-leaning and right-leaning papers among all groups appearing in our dataset.

Parallelism, defined as significant differences between the mix of groups used as sources between left- and right-leaning newspapers, is found in all three countries. We focus our attention on salient differences between our newspaper sources and among group types. First, as Table 2 illustrates, the differences in the media coverage of interest organizations in the UK are as expected. In this case, mean differences are significant for trade unions, business groups and public interest groups (see significance levels reported Table 2). In Denmark, business groups

52 See Halpin 2011. 
receive more attention in the right-leaning $J P$ and public interest groups more in Politiken, but a difference is also found for identity groups that get more coverage in $J P$. This is even more marked in Spain, where the right-leaning paper El Mundo pays more attention to identity groups and the left-leaning El Pais to institutional groups. This pattern may be explained by the prevalence of some issues on the political agenda, and more specifically to the importance that El Mundo places on the victims of ETA terrorism. ${ }^{53}$ Overall, these findings illustrate that media coverage is distributed unevenly across newspapers in all three countries.

\section{DISCUSSION AND CONCLUSION}

Media appearances can be a valuable asset for interest groups; however, there are clear limits on how many groups can be included in news stories. When explaining the patterns of group appearances in the news media, it is therefore necessary to draw on theories about media selection. Based on such theories, we developed expectations about: concentration in media attention, bias in the types of groups getting coverage, and differences across issue areas and newspapers of different political leanings. The article tested these expectations in the first multicountry study of media appearances by interest groups. By comparing three countries with different media systems, we have been able to demonstrate similarities as well as differences across countries.

In all countries, media attention is highly skewed. A small number of groups receive the vast majority of attention, while most other groups appear only once or twice in the material. From a normative perspective, this means that the range of voices available to citizens is far from an equal reflection of the interest group society. ${ }^{54}$ In particular, citizen groups are much less commonly referred to in the news than economic groups such as trade unions and business groups. With regard to the political process, to the extent that politicians rely on the media for input into their political work, it also means that the input received will be skewed towards certain interests. ${ }^{55}$ While many of the groups - such as major trade unions or business groups cited most often in the media represent broad encompassing interests, it is evident that biases are present in the way interest groups are used as sources, and that these biases are detrimental to the level of diversity in group media appearances.

The use of sources is highly dependent on the topics reported on, and large differences in patterns of group appearance are found across policy areas. In some issue areas economic groups are close to exercising complete dominance, while more diversity is found in other policy areas. Here, situational differences and country differences are also at play. The three countries have rather divergent interest group systems, and the policy agenda in the analyzed period differed. Most notably, the Spanish media paid a great deal of attention to the economic crisis and terrorism. These patterns also affected the comparison of right- and left-leaning papers, as the Spanish El Mundo paid a lot of attention to identity groups representing the victims of ETA terrorism. In addition, evidence of parallelism was found across all countries, with systematic differences in the patterns of group appearance in different papers.

In a situation in which ties between political parties and newspapers have loosened, and interest groups and parties are much less closely aligned than in previous decades, ${ }^{56}$ it is interesting that parallelism is present in the news coverage of groups. The three countries

53 Chaqués-Bonafont and Baumgartner 2013.

54 Tiffen et al. 2014.

55 Thrall 2006.

56 Allern and Bale 2012. 
TABLE 2 Media Coverage of Interest Groups across Countries and Newspapers (Mean Differences)

\begin{tabular}{|c|c|c|c|c|c|c|c|c|c|}
\hline Interest group & UK & Mean & $\begin{array}{c}\text { Sig. } \\
\text { bilateral }\end{array}$ & Spain & Mean & $\begin{array}{c}\text { Sig. } \\
\text { bilateral }\end{array}$ & Denmark & Mean & $\begin{array}{c}\text { Sig. } \\
\text { bilateral }\end{array}$ \\
\hline \multirow[t]{2}{*}{ Trade unions } & $\begin{array}{c}\text { The } \\
\text { Telegraph }\end{array}$ & 6.9 & \multirow[t]{2}{*}{0.007} & $\begin{array}{c}\text { El } \\
\text { Mundo }\end{array}$ & 14.7 & \multirow[t]{2}{*}{0.706} & $\begin{array}{l}\text { Jyllands- } \\
\text { Posten }\end{array}$ & 6.5 & \multirow[t]{2}{*}{0.959} \\
\hline & $\begin{array}{c}\text { The } \\
\text { Guardian }\end{array}$ & 10.5 & & El País & 15.5 & & Politiken & 6.5 & \\
\hline \multirow[t]{2}{*}{$\begin{array}{c}\text { Business } \\
\text { groups }\end{array}$} & $\begin{array}{l}\text { The } \\
\text { Telegraph }\end{array}$ & 4.0 & \multirow[t]{2}{*}{0.010} & $\begin{array}{c}\text { El } \\
\text { Mundo }\end{array}$ & 2.5 & \multirow[t]{2}{*}{0.594} & $\begin{array}{l}\text { Jyllands- } \\
\text { Posten }\end{array}$ & 6.4 & \multirow[t]{2}{*}{0.001} \\
\hline & $\begin{array}{c}\text { The } \\
\text { Guardian }\end{array}$ & 2.4 & & El País & 2.4 & & Politiken & 2.5 & \\
\hline \multirow[t]{2}{*}{$\begin{array}{l}\text { Institutional } \\
\text { groups }\end{array}$} & $\begin{array}{c}\text { The } \\
\text { Telegraph }\end{array}$ & 3.1 & \multirow[t]{2}{*}{0.435} & $\begin{array}{c}\text { El } \\
\text { Mundo }\end{array}$ & 0.6 & \multirow[t]{2}{*}{0.052} & $\begin{array}{l}\text { Jyllands- } \\
\text { Posten }\end{array}$ & 8.1 & \multirow[t]{2}{*}{0.580} \\
\hline & $\begin{array}{c}\text { The } \\
\text { Guardian }\end{array}$ & 2.7 & & El País & 2.9 & & Politiken & 7.6 & \\
\hline \multirow[t]{2}{*}{$\begin{array}{l}\text { Professional } \\
\text { groups }\end{array}$} & $\begin{array}{c}\text { The } \\
\text { Telegraph }\end{array}$ & 1.7 & \multirow[t]{2}{*}{0.877} & $\begin{array}{c}\text { El } \\
\text { Mundo }\end{array}$ & 2.2 & \multirow[t]{2}{*}{0.129} & $\begin{array}{l}\text { Jyllands- } \\
\text { Posten }\end{array}$ & 0.8 & \multirow[t]{2}{*}{0.897} \\
\hline & $\begin{array}{c}\text { The } \\
\text { Guardian }\end{array}$ & 1.7 & & El País & 1.3 & & Politiken & 0.8 & \\
\hline \multirow[t]{2}{*}{ Identity groups } & $\begin{array}{c}\text { The } \\
\text { Telegraph }\end{array}$ & 1.6 & \multirow[t]{2}{*}{0.301} & $\begin{array}{c}\text { El } \\
\text { Mundo }\end{array}$ & 2.3 & \multirow[t]{2}{*}{0.017} & $\begin{array}{l}\text { Jyllands- } \\
\text { Posten }\end{array}$ & 2.6 & \multirow[t]{2}{*}{0.031} \\
\hline & $\begin{array}{c}\text { The } \\
\text { Guardian }\end{array}$ & 1.9 & & El País & 0.7 & & Politiken & 1.8 & \\
\hline \multirow[t]{2}{*}{ Leisure groups } & $\begin{array}{l}\text { The } \\
\text { Telegraph }\end{array}$ & 1.2 & \multirow[t]{2}{*}{0.260} & $\begin{array}{c}\text { El } \\
\text { Mundo }\end{array}$ & 1.2 & \multirow[t]{2}{*}{0.606} & $\begin{array}{l}\text { Jyllands- } \\
\text { Posten }\end{array}$ & 1.4 & \multirow[t]{2}{*}{0.079} \\
\hline & $\begin{array}{c}\text { The } \\
\text { Guardian }\end{array}$ & 1.4 & & El País & 1.6 & & Politiken & 0.9 & \\
\hline \multirow[t]{2}{*}{$\begin{array}{l}\text { Public interest } \\
\text { groups }\end{array}$} & $\begin{array}{c}\text { The } \\
\text { Telegraph }\end{array}$ & 1.1 & \multirow[t]{2}{*}{0.000} & $\begin{array}{c}\text { El } \\
\text { Mundo }\end{array}$ & 1.6 & \multirow[t]{2}{*}{0.251} & $\begin{array}{l}\text { Jyllands- } \\
\text { Posten }\end{array}$ & 2.4 & \multirow[t]{2}{*}{0.014} \\
\hline & $\begin{array}{c}\text { The } \\
\text { Guardian }\end{array}$ & 1.9 & & El País & 2.0 & & Politiken & 3.3 & \\
\hline
\end{tabular}

represent different models of media and politics, and thus there is reason to believe that these results may be generalized to other European countries. Parallelism may come about not as a result of organizational links, but rather as an effect of competition between papers seeking their audience in niches identified by cultural, ideological and political commonalities. ${ }^{57}$ For readers of newspapers, this means that the selection of topics reported on, the framing of the stories and - as illustrated in this article - the set of organized interests they hear from depend on their choice of news outlet. If most citizens refer to only a limited set of media outputs, this will limit the diversity in the viewpoints to which they are exposed.

\section{REFERENCES}

Aalberg, Toril, Peter van Aelst, and James Curran. 2010. Media Systems and the Political Information Environment: A Cross-National Comparison. The International Journal of Press/ Politics 15:255-71.

57 Mancini 2012, 267. 
Ainsworth, Scott, and Itai Sened. 1993. The Role of Lobbyists: Entrepreneurs with Two Audiences. American Journal of Political Science 37:834-66.

Allern, Elin H., and Tim Bale. 2012. Political Parties and Interest Groups: Disentangling Complex Relationships. Party Politics 18:7-25.

Allern, Sigurd, and Mark Blach-Ørsten. 2011. The News Media as a Political Institution. A Scandinavian Perspective. Journalism Studies 12:92-105.

Baumgartner, Frank R., Jeffrey M. Berry, Marie Hojnacki, Beth L. Leech, and David C. Kimball. 2009. Lobbying and Policy Change: Who Wins, Who Loses, and Why. Chicago, IL: University of Chicago Press.

Baumgartner, Frank R., and Laura Chaqués-Bonafont. 2015. All News is Bad News. Newspaper Coverage of Political Parties in Spain. Political Communication 32:268-91.

Baumgartner, Frank R., Suzanna L. De Boef, and Amber E. Boydstun. 2008. The Decline of the Death Penalty and the Discovery of Innocence. New York: Cambridge University Press.

Bennett, W. Lance. 1990. Toward a Theory of Press-State Relations in the United States. Journal of Communication 40:103-25.

Berkhout, Joost. 2013. Why Interest Organizations Do What They Do: Assessing the Explanatory Potential of 'Exchange' Approaches. Interest Groups and Advocacy 2:227-50.

Berry, Jeffrey M. 1977. Lobbying for the People: The Political Behavior of Public Interest Groups. Princeton, NJ: Princeton University Press.

Beyers, Jan. 2004. Voice and Access. Political Practices of European Interest Associations. European Union Politics 5:211-40.

Binderkrantz, Anne. 2005. Interest Group Strategies: Navigating Between Privileged Access and Strategies of Pressure. Political Studies 53:694-715.

2008. Different Groups, Different Strategies: How Interest Groups Pursue Their Political Ambitions. Scandinavian Political Studies 51:157-84.

Binderkrantz, Anne S. 2012. Interest Groups in the Media. Bias and Diversity Over Time. European Journal of Political Research 51:117-39.

Binderkrantz, Anne S., and Peter Munk Christiansen. 2010. Tordenskjolds soldater. Interesseorganisationer i medierne. [Tordenskjold's Soldiers. Interest Groups in the Media] Politica 42:27-48.

2013. Making It to the News. Interest Groups in the Danish Media. In Politische Interesenvermittlung und Medien edited by Franziska Oehmer, 201-19. Baden-Baden: Nomos.

Binderkrantz, Anne Skorkjær, and Peter Munk Christiansen. 2015. From Classic to Modern Corporatism. Interest Group Representation in Danish Public Committees in 1975 and 2010. Journal of European Public Policy 22 (7):1022-39.

Binderkrantz, Anne S., Helene Helboe Pedersen, and Peter Munk Christiansen. 2015. Interest Group Access to the Administration, Parliament and Media. Governance 28:95-112.

Binderkrantz, Anne Skorkjær, and Anne Rasmussen. 2015. Comparing the Domestic and the EU Lobbying Context: Perceived Agenda-Setting Influence in the Multi-Level System of the European Union. Journal of European Public Policy 22 (4):552-69.

Blumler, Jay G., Jack M. McLeod, and Karl Erik Rosengren. 1992. Comparatively Speaking: Communication and Culture Across Space and Time. London: SAGE Series in Communication Research.

Bouwen, Pieter. 2004. Exchanging Goods for Access: A Comparative Study of Business Lobbying in the European Union Institutions. European Journal of Political Research 43:337-69.

Boydstun, Amber. 2013. Making the News. Politics, the Media and Agenda Setting. Chicago, IL: University of Chicago Press.

Boydstun, Amber E., Shaun Bevan, and Herschel F. Thomas III. 2014. The Importance of Attention Diversity and How to Measure It. Policy Studies Journal 42:173-96.

Castells, Manuel. 2009. Communication Power. Oxford: Oxford University Press.

Chaqués-Bonafont, Laura, and Frank R. Baumgartner. 2013. Newspaper Attention and Policy Activities in Spain. Journal of Public Policy 33:65-88.

Christiansen, Peter Munk. 2012. The Usual Suspects: Interest Group Dynamics and Representation in Denmark. In The Scale of Interest Organization in Democratic Politics. Data and Research Methods, edited by Darren Halpin and Grant Jordan, 161-79. Houndmills, Basingstoke: Palgrave Macmillan. 
Cook, Thimothy E. 1998. Governing with the News. The News Media as a Political Institution. Chicago, IL: University of Chicago Press.

Danielian, Lucig H., and Benjamin I. Page. 1994. The Heavenly Chorus: Interest Group Voices on TV News. American Journal of Political Science 38:1056-78.

de Bruycker, Iskander, and Jan Beyers. 2015. Balanced or Biased? Interest Groups and Legislative Lobbying in the European News Media. Political Communication 32:453-74.

Dimitrova, Daniela V., and Jesper Strömbäck. 2009. Look Who's Talking. Use of Sources in Newspaper Coverage in Sweden and the United States. Journalism Practice 3:75-91.

Dunleavy, Patrick. 1991. Democracy, Bureaucracy and Public Choice. Economic Explanations in Political Science. New York: Harvester/Wheatsheaf.

Galtung, Johan, and Mari Holmboe Ruge. 1965. The Structure of Foreign News. Journal of Peace Research 2:64-91.

Graber, Doris. 2003. The Power of Communication. Managing Information in Public Organizations. Washington, DC: CQ Press.

Grossmann, Matt. 2012. The Not-So-Special Interests. Interest Groups, Public Representation. and American Governance. Stanford: Stanford University Press.

Gunther, Richard, and Anthony Mughan. 2000. Democracy and the Media. Cambridge: Cambridge University Press.

Hallin, Daniel C., and Paolo Mancini. 2004. Comparing Media Systems. Three Models of Media and Politics. New York: Cambridge University Press.

Halpin, Darren. 2011. Organized Interests and Cascades of Attention: Unpacking Policy Bandwagon Dynamics. Governance: An International Journal of Policy, Administration, and Institutions 24:205-30.

Halpin, Darren, and Anne S. Binderkrantz. 2011. Explaining Breadth of Policy Engagement: Patterns of Interest Group Mobilization in Public Policy. Journal of European Public Policy 18:201-19.

Halpin, Darren, Graeme Baxter, and Iain MacLeod. 2012. Multiple Arenas, Multiple Populations: Counting Organized Interests in Scottish Public Policy. In The Scale of Interest Organization in Democratic Politics. Data and Research Methods, dited by Darren Halpin and Grant Jordan, 118-40. Houndmills, Basingstoke: Palgrave Macmillan.

Halpin, Darren, and Herschel F. Thomas III. 2012. Evaluating the Breadth of Policy Engagement by Organized Interests. Public Administration 90:582-99.

Hänggli, Regula. 2012. Key Factors in Frame Building: How Strategic Actors Shape News Media Coverage. American Behavioral Scientist 56:300-17.

Hjarvard, Stig. 2008. En verden af medier. Medialiseringen af politik, sprog, religion og leg. Copenhagen: Samfundslitteratur.

Iyengar, Shanto, and Jennifer A. McGrady. 2007. Media Politics: A Citizen's Guide. New York: W.W. Norton \& Company.

Kriesi, Hanspeter, Anke Tresch, and Margit Jochum. 2007. Going Public in the European Union. Action Repertoires of Western European Collective Political Actors. Comparative Political Studies 40:48-73.

Lowery, David, and Virginia Gray. 2004. Bias in the Heavenly Chorus: Interests in Society and Before Government. Journal of Theoretical Politics 16:5-30.

Mancini, Paolo. 2012. Instrumentalization of the Media vs. Political Parallelism. Chinese Journal of Communication 5:262-80.

Molina, Oscar, and Martin Rhodes. 2002. Corporatism: The Past, Present, and Future of a Concept. Annual Review of Political Science 5:305-31.

Olson, Mancur. 1965. The Logic of Collective Action. Public Goods and the Theory of Groups. Cambridge, MA: Harvard University Press.

Rokkan, Stein. 1966. Norway: Numerical Democracy and Corporate Pluralism. In Political Oppositions in Western Democracies, edited by Robert A. Dahl, 75-115. New Haven, CT: Yale University Press.

Schattschneider, Elmer E. 1975 [1969]. The Semisovereign People. A Realist's View of Democracy in America. US: Thomson Learning.

Schlozman, Kay L. 1984. What Accent the Heavenly Chorus? Political Equality and the American Pressure System. Journal of Politics 46:1006-32. 
Schlozman, Kay L., Sidney Verba, and Henry E. Brady. 2012. The Unheavily Chorus. Unequal Political Voice and the Broken Promise of American Democracy. Princeton, NJ: Princeton University Press. Seymour-Ure, Colin. 1974. The Political Impact of Mass Media. London: Constable/Sage.

Stromback, Jesper, and Peter van Aelst. 2013. Why Political Parties Adapt to the Media: Exploring the Fourth Dimension of Mediatization. International Communication Gazette 75:341-58.

Thrall, Trevor A. 2006. The Myth of the Outside Strategy: Mass Media News Coverage of Interest Groups. Political Communication 23:407-20.

Thrall, Trevor A., Dominik Stecula, and Diana Sweet. 2014. May We Have Your Attention Please? Human-Rights NGOs and the Problem of Global Communication. The International Journal of Press/Politics 19:135-9.

Tiffen, Rodney, Paul K. Jones, David Rowe, Toril Aalberg, Sharon Coen, James Curran, Kaori Hayashi, Shanto Iyengar, Gianpietro Mazzoleni, Stylianos papathanassopoulos, Hernando Rojas, and Stuart Soroka. 2014. Sources in the News. Journalism Studies 15:374-91.

Tilly, Charles, and Sidney Tarrow. 2006. Contentious Politics. Boulder, CO: Paradigm Publishers.

Tresch, Anke. 2009. Politicians in the Media: Determinants of Legislators' Presence and Prominence in Swiss Newspapers. The International Journal of Press/Politics 14:67-90. 